\title{
THE PERFORMANCE OF MILK PRODUCTION, TOTAL MILK REVENUE AND REPRODUCTION INDICATORS ON DAIRY SMALLHOLDERS IN YOGYAKARTA AND EAST JAVA, INDONESIA*
}

\author{
PRODUKSI SUSU, TOTAL PENERIMAAN SUSU DAN INDIKATOR-INDIKATOR \\ REPRODUKSI PADA PETERNAK SAPI PERAH RAKYAT DI YOGYAKARTA DAN JAWA \\ TIMUR, INDONESIA
}

\author{
Sudi Nurtini*, Rochijan, Budi Guntoro, Budi Prasetyo Widyobroto, Indratiningsih and \\ Nafiatul Umami \\ Faculty of Animal Science, Universitas Gadjah Mada, Yogyakarta, 55281
}

Submitted: 21 March 2017, Accepted: 6 April 2017

\begin{abstract}
The purpose of this study was to analyze the performance of milk production, total milk revenue and reproduction indicators of Friesian Holstein Crossbred cows maintained under smallholder's management system of 122 cows in DIY Province and 345 cows in East Java Province, Indonesia. The study was conducted with survey method and direct observation. A total of 180 Friesian Holstein Crossbred farmers (90 farmers were in DIY and another 90 farmers were from East Java Province) was randomly selected and interviewed used structured questionnaire to assess the milk production, total milk revenue and indicators of reproduction of Friesian Holstein Crossbred cows. The result of the study showed that the average mature equivalent of milk production was 3,810.21 $\pm 920.10 \mathrm{~L} /$ lactation in DIY and $3,717.79 \pm 818.44$ L/lactation in East Java Province, and the total milk revenue was $12,401,917.87 \pm 2.48$ IDR per lactation in DIY and 14,647,217.80 3 3.05 IDR per lactation in East Java Province; day to first mating (postpartum mating), services per conception and days open were $62.34 \pm 29.24$ days, $2.60 \pm 1.32$ and $88.58 \pm 34.43$ days in DIY and $60.62 \pm 23.07$ days, $2.46 \pm 1.26$ and $88.67 \pm 28.86$ days in East Java Province. Based on total milk revenue, the conclusion of this study was Friesian Holstein Crossbred cows maintained under smallholder's management system in East Java Province better than those in Yogyakarta province (DIY). The mature equivalent of milk production and reproduction indicators of dairy cows (postpartum mating, service per conception and days open) from both provinces showed no significant differences and the value of each parameter reproduction indicators is still within the normal range.
\end{abstract}

(Keywords: Dairy smallholder, Milk production, Reproduction performance, Total milk revenue)

\section{INTISARI}

Penelitian ini bertujuan untuk menganalisis produksi susu, total penerimaan susu dan indikatorindikator reproduksi dari sapi-sapi Peranakan Frisian Holstein yang dipelihara oleh peternak sapi perah rakyat sejumlah 122 ekor di propinsi Daerah Istimewa Yogyakarta dan 345 ekor di Propinsi Jawa Timur, Indonesia. Penelitian dilaksanakan dengan metode survei dan pengamatan langsung. Sejumlah 180 peternak sapi perah Peranakan Frisian Holstein (90 peternak dari Propinsi DIY dan 90 peternak dari Propinsi Jawa Timur) dipilih secara random dan diwawancarai dengan menggunakan daftar pertanyaan yang terstruktur untuk mendapatkan data produksi susu, total penerimaan dari susu dan indikatorindikator reproduksi dari sapi perah Peranakan Frisian Holstein. Hasil penelitian menunjukkan bahwa rata-rata produksi susu setara mature equivalent adalah 3.810,21 $\pm 920,10$ L/laktasi di DIY dan

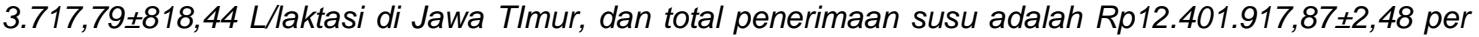
laktasi di DIY dan Rp14.647.217,80 $\pm 3,05$ per laktasi di Jawa Timur; postpartum mating, service per conception dan days open di DIY dan Jawa TImur masing-masing berturur-turut adalah 62,34 $\pm 29,24$ hari,

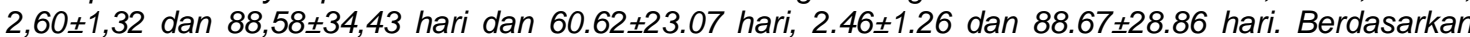
total penerimaan dari susu, dapat disimpulkan bahwa pada penelitian ini sapi perah Peranakan Friesian Holstein yang dipelihara peternak sapi perah rakyat di provinsi Jawa Timur lebih baik daripada di provinsi

* Selected paper of the $1^{\text {st }}$ International Conference on Tropical Agriculture (ICTA) 2016

\footnotetext{
* Korespondensi (corresponding author):

Telp. +62 8164221579

E-mail: nurtini@ugm.ac.id
} 
Yogyakarta (DIY). Produksi susu setara mature equivalent dan kinerja reproduksi sapi perah (postpartum mating; service per conception dan days open) dari kedua propinsi tidak menunjukkan perbedaan yang nyata dan nilai dari masing-masing parameter kinerja reproduksi masih dalam kisaran normal.

(Kata kunci: Penampilan reproduksi, Peternak sapi perah rakyat, Produksi susu, Total penerimaan susu)

\section{Introduction}

Dairy farming represented as important sources for providing milk requirement in Indonesia. Milk consumption increased from $0.104 \mathrm{~L} / \mathrm{c} a \mathrm{p} i \mathrm{ta} / \mathrm{year}$ fresh milk consumption in 2010 to 0.156 L/capita/year in 2014 (Dirjen Peternakan dan Kesehatan Hewan, 2015). East Java accounted for $48 \%$ of the total dairy cow numbers in Indonesia (Animal Husbandry Department, 2011). As the center of dairy cattle development, East Java has about 253,830 heads with 426,557 tons/year of milk production and DIY has about 4,504 heads with 6,626 tons/year of milk production by the year of 2015 (Dirjen Peternakan dan Kesehatan Hewan, 2015).

The main purposes-of maintaining dairy cattle are milk production and calf, savings, cost of school children, and produce organic fertilizer. Dairying is implemented a tradition practice in milk production for a longer time period and mostly operated by smallholder farmers who raise about 2 to 5 cows. Dairy farming as a part of a farming system has become increasingly important as an aspect of labor and income generating activities of farm households. Utami and Seruni (2013) discovered that household labor was allocated more to dairy farming compared to the farm and non-farm work which female participation was most evident in feed preparation and feeding, whereas the predominant male activity was forage collection for the dairy cattle then the children just assisted the activities alone.

The potential for livestock development in Indonesia is very high, with the support of abundant resources. Studies on dairy farming indicated that livestock can provide additional income and employment to households, especially in developing countries (Piraux et al., 1996). Farming of dairy animals not only increases the level of expected income but also reduces the magnitude of income risk (Bhende and Venkataram, 1994). For instance, the dairy cattle in Bangladesh are proposed as a supplementary income source for smallholders (Wimaladharma, 1985). Similarly, dairy farming is found beneficial in terms of increasing income and generating employment (Ravindra and Veerabhadraiah, 1991). Therefore, dairy farming can increase villager's life standards and growth income in the area where land holding is inadequate and unbalanced (Kocturk, 2009). Mumba et al. (2011) found that smallholder's dairy farming in Zambia has an important role in rural development and poverty alleviation. The effect of milk production and milk total revenue will also affect the reproductive performance of dairy farm income, additional income and employment opportunities for family members. The purpose of this study was to analyze the performance of milk production, total milk revenue and reproduction indicators of Friesian Holstein Crossbred cows maintained under smallholder's management system of 122 cows in DIY and 345 cows in East Java Province, Indonesia.

\section{Material and Method}

\section{Materials}

The respondent was dairy farmers from DIY Province at district Sleman and East Java Province at district Pasuruan, Malang and Batu. The research was conducted by survey method and the technique of triangulation: a questionnaire to farmers, in-depth interviews, and focus group discussion. A total of 180 Friesian Holstein Crossbred farmers (90 farmers were in DIY and another 90 farmers were in East Java Province) were randomly selected and interviewed with a structured questionnaire to assess the milk production, total milk revenue and indicators of reproduction of Friesian Holstein Crossbred cows.

\section{Methods}

Two data collection techniques were used, namely: 1) observation, data collected by directly observing and taking samples from the object of research; and 2) interview, namely the collection of data by requesting information from respondents; while secondary data using recording techniques; namely the collection of data by recording data that were already existed in the 
department or institution related to this research.

\section{Data analysis}

Revenue referred to compute the value of output. The revenue is defined as output multiplied by the price of output (Ibrahim, 2009). The equation of revenue or total milk revenue is presented as:

$\mathrm{TR}=\mathrm{Pq} \times \mathrm{Q}$

which:

$\mathrm{TR}=$ Total revenue received from selling fresh dairy milk (IDR/year).

$\mathrm{Q}=$ Quantity of fresh dairy milk (IDR/year).

$\mathrm{Pq}=$ The price of fresh dairy milk (IDR/year).

The data were entered into MS Excel spreadsheet and transferred to analytical software SPSS 17 for t-test analysis.

\section{Result and Discussion}

\section{Socio-economic characteristics of respondents}

The characteristic of respondents or farmers includes age, education, occupation, and farming purpose, as well as farming objectives influencing the pattern of raising dairy cows. Farmer characteristic data can be seen in Table 1.

The Table 1 shows that the $40-59$ age group is the group of smallholders that has the largest percentage amount in Yogyakarta and East Java. East Java has other major groups of $30-39$. East Java has an average age of farmers who are younger than those in DIY, with an average of $41.83 \pm 12.48$ years and DIY has an average of $49.49 \pm 11.31$ years. More than $50 \%$ of farmers with low education and no schooling. This shows that there is still a lack of human resources in formal education. In general, they were dominated by elementary level. In addition to formal education, it is also supported by non-formal education such as training and counseling on the maintenance of dairy cows, feed, artificial insemination, fertilizer processing, dairy processing, and animal health $(>50 \%)$. Farmers who no schooling in DIY as much as $16.67 \%$ and East Java $10.00 \%$. Working as dairy farmers is the mainstay for farmers in DIY and East Java. While most farmers do not have a second job, in addition to working in a dairy cattle.

The purpose of raising dairy cattle by farmers (Table 1) prioritized on milk production (priority 1), savings (priority 2) and cost of children education (priority 3) for farmers in DIY and East Java. The purpose other than maintenance is for manure as fertilizer priority 4 in DIY and priority 5 in East Java, as well as companion animals or for pleasure (hobby) priority 5 in DIY and priority 4 in East Java.

Cattle ownership, milk production, and total milk revenue

Cattle ownership and milk production. The ownership of dairy cows varies greatly between the two provinces. In terms of ownership of cattle, farmers in East Java have cattle more than those farmers in DIY. Meanwhile, in terms of milk production mature equivalent (ME), milk production in DIY better than those in East Java. Table 2 shows that the two provinces in an average of cattle ownership are still under economies of scale as suggested Ahmad and Hermiyetti (2008) that is 10 to 12 heads/farmer. Farmers in East Java approaching economies of scale, even exceeding the recommended, Setiani and Prasetyo (2008) reported that dairy farm household level can provide benefits if the amount kept at least 6 heads. The composition of lactating dairy cows ownership still needs to be improved because it has not reached the requirement to provide a business advantage that is $\geq$ $70 \%$ (Nurtini, 2006). Conditions of cattle ownership are low partly caused by lack of capital and difficulty of finding forage due to limited land for fodder crops to supply the quantity and quality of feed is also limited. This situation led to dairy farming has not been efficient (Priyanti et al., 2009).

Lactation cow proportion is still low and yet achieved economic standard shows that the burden of the lactating cows is high enough to bear the cost of production for cows that do not produce. However, this proportion has increased over the study Priyanti et al. (2009) in the provinces of West Java, Central Java, DIY and East Java, which on average is only $51.6 \%$. Ownership male calf is relatively small because in general the male calves are sold at the age of 6 to 12 months. Female calf maintained as they are used as a relatively small replacement. Daily milk production should reach at least about $10 \mathrm{~L} / \mathrm{head} / \mathrm{day}$. The highest milk production mature equivalent (ME) achieved by farmers in DIY, followed by farmers in East Java. This condition is 
caused by mostly respondents in DIY have used milking machine, while all of the respondents in East Java used manual for milking.

Total milk revenue. Capital has a potential role in representing the financial structure controlled by the smallholder dairy farming. It is divided into two types of asset, namely fixed asset and working capital.

Table 2 shows total milk revenue from dairy farming was primarily derived from East Java was marginally higher $(14,647,217.80 \pm 3.05 \quad$ IDR/lactation) than those from DIY $(12,401,917.87 \pm 2.48$

Table 1. Characteristics of respondent

\begin{tabular}{|c|c|c|c|c|c|}
\hline & \multirow{3}{*}{$\begin{array}{l}\text { Parameters } \\
<20\end{array}$} & \multicolumn{4}{|c|}{ Province } \\
\hline & & \multicolumn{2}{|c|}{ Daerah Istimewa Yogyakarta } & \multicolumn{2}{|c|}{ East Java } \\
\hline \multirow{9}{*}{$\begin{array}{l}\text { Age group } \\
\text { (year) }\end{array}$} & & 0 & $(0.00 \%)$ & 1 & $(1.11 \%)$ \\
\hline & $20-29$ & 1 & $(1.11 \%)$ & 14 & $(15.56 \%)$ \\
\hline & $30-39$ & 16 & $(17.78 \%)$ & 25 & $(27.78 \%)$ \\
\hline & $40-49$ & 26 & $(28.89 \%)$ & 22 & $(24.44 \%)$ \\
\hline & $50-59$ & 27 & $(30.00 \%)$ & 19 & $(21.11 \%)$ \\
\hline & $60-69$ & 15 & $(16.67 \%)$ & 7 & $(7.78 \%)$ \\
\hline & $70-79$ & 3 & $(3.33 \%)$ & 1 & $(1.11 \%)$ \\
\hline & $80-89$ & 2 & $(2.22 \%)$ & 1 & $(1.11 \%)$ \\
\hline & $\begin{array}{l}\text { Total of respondent / farmer } \\
\text { Average of age (year) }\end{array}$ & $\begin{array}{r}90 \\
49.49 \\
\end{array}$ & $\begin{array}{l}(100.00 \%) \\
+11.31 \\
\end{array}$ & $\begin{array}{l}90 \\
41.8\end{array}$ & $\begin{array}{l}(100.00 \%) \\
3 \pm 12.48\end{array}$ \\
\hline \multirow{6}{*}{$\begin{array}{l}\text { Formal } \\
\text { education }\end{array}$} & No schooling & 15 & $(16.67 \%)$ & 9 & $(10.00 \%)$ \\
\hline & Elementary school & 43 & $(47.78 \%)$ & 57 & $(63.33 \%)$ \\
\hline & Junior high school & 10 & $(11.11 \%)$ & 14 & $(15.56 \%)$ \\
\hline & Senior high school & 21 & $(23.33 \%)$ & 8 & $(8.89 \%)$ \\
\hline & College / university & 1 & $(1.11 \%)$ & 2 & $(2.22 \%)$ \\
\hline & Total of respondent / farmer & 90 & $(100.00 \%)$ & 90 & $(100.00 \%)$ \\
\hline \multirow{17}{*}{ Job (occupation) } & Main job (occupation): & & & & \\
\hline & Dairy farmer & 72 & $(80.00 \%)$ & 81 & $(90.00 \%)$ \\
\hline & Rice farmer & 14 & $(15.56 \%)$ & 5 & $(5.56 \%)$ \\
\hline & Retailer & 1 & $(1.11 \%)$ & 0 & $(0.00 \%)$ \\
\hline & Cooperative staff & 0 & $(0.00 \%)$ & 2 & $(2.22 \%)$ \\
\hline & Private company staff & 2 & $(2.22 \%)$ & 1 & $(1.11 \%)$ \\
\hline & Government officer & 1 & $(1.11 \%)$ & 1 & $(1.11 \%)$ \\
\hline & Total of respondent / farmer & 90 & $(100.00 \%)$ & 90 & $(100.00 \%)$ \\
\hline & Second job (occupation): & & & & \\
\hline & None & 46 & $(51.11 \%)$ & 48 & $(53.33 \%)$ \\
\hline & Dairy farmer & 18 & $(20.00 \%)$ & 9 & $(10.00 \%)$ \\
\hline & Rice farmer & 11 & $(12.22 \%)$ & 18 & $(20.00 \%)$ \\
\hline & Retailer & 5 & $(5.56 \%)$ & 13 & $(14.44 \%)$ \\
\hline & Cooperative staff & 1 & $(1.11 \%)$ & 1 & $(1.11 \%)$ \\
\hline & Private company staff & 8 & $(8.89 \%)$ & 1 & $(1.11 \%)$ \\
\hline & Government officer & 0 & $(0.00 \%)$ & 0 & $(0.00 \%)$ \\
\hline & Total of respondent / farmer & 90 & $(100.00 \%)$ & 90 & $(100.00 \%)$ \\
\hline \multirow{5}{*}{$\begin{array}{l}\text { Farming } \\
\text { purpose }\end{array}$} & Priority 1 & \multicolumn{2}{|c|}{ Milk production } & \multicolumn{2}{|c|}{ Milk production } \\
\hline & Priority 2 & \multicolumn{2}{|c|}{ Saving } & \multicolumn{2}{|c|}{ Saving } \\
\hline & Priority 3 & \multicolumn{2}{|c|}{ Children's education } & \multicolumn{2}{|c|}{ Children's education } \\
\hline & Priority 4 & \multirow{2}{*}{\multicolumn{2}{|c|}{$\begin{array}{c}\text { Fertilizer } \\
\text { Companion animal }\end{array}$}} & \multirow{2}{*}{\multicolumn{2}{|c|}{$\begin{array}{c}\text { Companion animal } \\
\text { Fertilizer }\end{array}$}} \\
\hline & Priority 5 & & & & \\
\hline
\end{tabular}


Table 2. Ownership of cattle, milk production, and total milk revenue in dairy smallholders

\begin{tabular}{lccc}
\hline \hline \multicolumn{1}{c}{ Parameters } & \multicolumn{2}{c}{ Province } & \multirow{2}{*}{ Significant } \\
\cline { 2 - 3 } & Daerah Istimewa Yogyakarta & East Java & \\
\hline Number of cattle owned (AU) & $3.56 \pm 2.12$ & $8.85 \pm 7.02$ & $0.000^{*}$ \\
Animal status (\%): & $53.60 \pm 27.17$ & $64.95 \pm 21.42$ & $0,000^{*}$ \\
$\quad$ Lactation & $8.88 \pm 22.59$ & $10.22 \pm 16.18$ & $0.960^{\text {ns }}$ \\
Non-lactation (dry) & $22.66 \pm 20.87$ & $10.84 \pm 13.98$ & $0.000^{*}$ \\
Heifer & 0.00 & $3.00 \pm 8.21$ & $0.001^{*}$ \\
Bull & $5.87 \pm 13.15$ & $2.91 \pm 5.79$ & $0.021^{*}$ \\
Male calf & $8.99 \pm 11.34$ & $8.08 \pm 9.10$ & $0.035^{\star}$ \\
Female calf & $3,810.21 \pm 920.10$ & $3,717.79 \pm 818.44$ & $0.300^{\text {ns }}$ \\
Mature equivalent of milk & $12,401,917.87 \pm 2.48$ & $14,647217.80 \pm 3.05$ & $0.000^{*}$ \\
production (L/lactation) & & &
\end{tabular}

IDR/lactation). This can be influenced by the milk production of dairy cows and the price per litre of milk at the level of farmers and cooperatives. It is importance to understand that the price of milk per litre in DIY is lower than in East Java, that is the milk price in DIY is 3,077.28 IDR per litre and in East Java is 4,616.52 IDR per litre.

The profitable farm in East Java is due to the household involvement that can reduce the expenses in operating dairy farming, with the indicated number of farmers in East Java is in the age of 30-39 years and the Main occupation is a dairy farmer with a value of $90.00 \%$ (Table 1). This finding was similar to Utami and Seruni (2013) that household labor including women has a higher participation in the dairy farming sector, especially in developing countries. Likewise, the previous study (Piraux et al., 1996) claimed that livestock farming can enhance learning for rural people who have a limited access to land to have a good living standard (Kocturk, 2009). Therefore, the rural labor empowerment in dairy farming will lift up their income and it can be used as a mean to alleviate poverty among villagers (Mumba et al., 2011).

Efficiency in raising dairy farming should be measured by R/C ratio. Smallholder's dairy farming indicated efficient $(\mathrm{R} / \mathrm{C}$ ratio $>1)$ in rearing dairy cattle. But by looking at the total milk revenue, has also shown the economic value to be received by farmers.

\section{Performance reproduction}

Success of reproduction performance is mainly determined by days open, the longer days open means the longer calving interval which affects the lowering amount of milk production throughout the cow life (Rochijan et al., 2016). Reproductive performance of dairy cattle at the smallholder vary greatly, it is possible for a lot of factors that don't support the maintenance management of dairy cattle. The results overall of reproduction performance was presented in Table 3.

Day to first breeding I Postpartum mating (PPM). The result shows that the shortest average PPM found in East Java is $60.62 \pm 23.07$ days and Daerah Istimewa Yogyakarta is $62.34 \pm 29.24$ days. Based on the PPM data obtained, the two provinces still in the normal range of the first time cows mating after parturition. It's lower than Pramono (2008) research about in Daerah Istimewa Yogyakarta value $4.21 \pm 1.20$ month. This range confirms Salisbury and Vandemark (1993) opinion that first mating is the best performed within 60 to 90 days after parturition cows. The lower of PPM value, it will be more efficient the reproduction performance of dairy cows. The difference in PPM on each cow is caused by differences in the occurrence of oestrous as the result of milk production difference which will cause weight loss. Therefore, the time to achieve the normal body weight for reproduction will be varies. These variations are caused by differing negative energy, which triggers reproductive problems such as sub oestrous and silent heat or quiet ovulation, as stated by Peters and Ball (1995), that very low feed quality and quantity are the main causes of anoestrous and the prolonging of the oestrous period after parturition.

Service per conception (S/C). The result shows that the shortest average S/C found in East Java is $2.46 \pm 1.26$ and Daerah Istimewa Yogyakarta is $2.60 \pm 1.32$. It's higher than Pramono (2008) research about in Daerah Istimewa Yogyakarta value $1.98 \pm 0.91$. This long interval or $S / C$ greater is due to silent oestrous caused by negative nutrient imbalance. This is parallel with 
Table 3. Average of reproduction performance in dairy cows

\begin{tabular}{lccc}
\hline \hline \multirow{2}{*}{ Parameters } & \multicolumn{2}{c}{ Province } & \multirow{2}{*}{ Significant } \\
\cline { 2 - 3 } & Daerah Istimewa Yogyakarta & East Java & \\
\hline Day to first mating / Postpartum mating (day) & $62.34 \pm 29.24$ & $60.62 \pm 23.07$ & $0.509^{\text {ns }}$ \\
Service per conception & $2.60 \pm 1.32$ & $2.46 \pm 1.26$ & $0.317^{\text {ns }}$ \\
Days open (day) & $88.58 \pm 34.43$ & $88.67 \pm 28.86$ & $0.977^{\text {ns }}$ \\
\hline ns = Non significant (P>0.05). & \multicolumn{3}{l}{}
\end{tabular}

Perry (1984) cit. Rochijan et al. (2016) opinion, who said that lack of energy after giving birth will extend estrous interval and will delay ovulation. Yifat et al. (2009) stated that appropriate and in time heat detection and insemination could be attributed to lower or higher number of service of per conception. The findings of the present study on services per conception suggested comparatively better insemination services at the herds during the period of the study, because S/C value is normal and nothing $>$ 2.00. López-Gatius et al. (2005) state that the success of the S/C has an important role in efforts to obtain optimum calving interval. It was further reported that the success of the $\mathrm{S} / \mathrm{C}$ is influenced by several factors such as detection of oestrous, condition of cows, as well as the skill and precision inseminator.

Days open (DO). The result shows that the shortest average PPM found in Daerah Istimewa Yogyakarta is $88.58 \pm 34.43$ days and East Java is $88.67 \pm 28.86$ days. The value of DO in East Java has long days open, this not in line with Antiyatmi (2009), that the optimal days open or the safest time to bring a cow into mating again is between 60 to 90 days after parturition, if it is too long, production during the next lactation period will decrease between 75 to 110 days. The long days open period is caused by the decrease of PPM and by the high service per conception. The long days open period will extend calving interval, which will decrease the number of calves produced throughout the cow lifetime. This in line with the opinion of Foley et al. cit. Rochijan et al. (2016) that the long days open will be lower the cow's productivity during its lifetime. Yaniz et al. (2006) stated that the delay in open days will directly cause calving interval length as a result of delayed pregnancy.

\section{Conclusion}

Total milk revenue in East Java higher than it is in Yogyakarta (DIY). This is influenced by the price of milk in liters and milk production of cows by each dairy smallholder (the milk price per litre in East Java is higher than it is in DIY), so the total milk revenue is significantly different that is higher in East Java than in DIY. The mature equivalent of milk production and reproduction indicators at both sides are the same.

\section{Acknowledgements}

This study was funded by the Directorate of Higher Education, the Ministry of Research, Technology and Higher Education, Republic of Indonesia (through PUPT Grant 2016), and Universitas Gadjah Mada.

\section{References}

Ahmad, I. dan Hermiyetti. 2008. Analisis produksi dan konsumsi susu di Indonesia. Prosiding Seminar Nasional Prospek Industri Sapi Perah Menuju Perdagangan Bebas 2020. Jakarta. 21 April 2008. Pusat Penelitian dan Pengembangan Peternakan Bogor bekerjasama dengan Sekolah Tinggi Ilmu Ekonomi Keuangan dan Perbankan Indonesia.

Animal Husbandry Department. 2011. Fresh Milk Production in East Java. Animal Husbandry Department East Java, Indonesia, Surabaya.

Antiyatmi. 2009. Reproductive performance of Friesian Holstein dairy cows of three age group at Pasir Salam animal husbandry Sukabumi West Java. Undergraduate Thesis S.Pt. Faculty of Animal Science, Universitas Gadjah Mada, Yogyakarta.

Bhende, M. J. and J. V. Venkataram. 1994. Impact of diversification on household income and risk: a wholefarm modelling approach. CAB Abstracts 1993-1994.

Dirjen Peternakan dan Kesehatan Hewan. 2015. Livestock and animal health 
statistcs 2015. Ministry of Agriculture, Republic of Indonesia, Jakarta.

Ibrahim, Y. 2009. Business Feasibility Study. Revised Edition. Rineka Cipta, Jakarta.

Kocturk, O. M. 2009. A case study of increasing income of dairy cattle in rural areas in western part of turkey. J. Anim. Vet. Adv. 8: 1685-1699.

López-Gatius, F., P. Santolaria, I. Mundet and J. L. Yániz. 2005. Walking activity at estrus and subsequent fertility in dairy cows. Theriogenology. 63: 14191429.

Mumba, C., K. L. Samui, G. S. Pandey, B. M. Hang'ombe, M. Simuunza, G. Tembo and S. W. Muliokela. 2011. Economic analysis of the viability of Smallholder dairy farming in Zambia. Livestock Res. Rural Dev. 23.

Nurtini, S. 2006. Insentif ekonomi dan daya saing usahatani sapi perah penghasil bahan baku industri pengolahan susu (IPS) di Daerah Istimewa Yogyakarta. Doctoral Thesis Sekolah Pascasarjana, Universitas Gadjah Mada, Yogyakarta.

Peters, A. K. and P. J. H. Ball. 1995. Reproduction in cattle, butterworth and co borough green. Sevenoaks Kent TN 158, England.

Piraux, M., A. Buldgen, F. Drugmant, M. Fall and R. Compare. 1996. Adoption of framing strategies to climatic risk and demographic pressure in the senegalese sahelo Sudanian Region. CAB Abstracts 1996-1997.

Pramono, A. 2008. Calving interval sapi perah di daerah istimewa Yogyakarta ditinjau dari kinerja reproduksi dan imbangan ransum yang diberikan. Thesis M.Sc. Faculty of Animal Science, Universitas Gadjah Mada, Yogyakarta.

Priyanti, A., S. Nurtini, dan A. Firman. 2009. Analisis ekonomi dan aspek sosial usaha sapi perah. Profil Usaha Peternakan di Indonesia. Pusat Penelitian Pengembangan Peternakan. Badan Penelitian dan Pengembangan Pertanian. Jakarta: LIPI Press.

Ravindra, R. and V. Veerabhadraiah. 1991. A Critical analysis of the impact of antyodaya programme on rural beneficiaries in Karnataka. CAB Abstracts 1991-1994.

Rochijan, B. P. Widyobroto and Ismaya. 2016. The impact of high rumen undegraded protein (HRUP) supplementation to blood urea nitrogen and reproduction performance in early lactation dairy cows. Int. J. Dairy Science. 11: 28-34.

Salisbury, G. W. and A. L. Vandemark. 1993. Physiology Reproduction and Artificial Insemination in Cattle (Fisiologi Reproduksi dan Inseminasi Buatan pada Sapi). Translated by R. Djanuar. Gadjah Mada University Press, Yogyakarta.

Setiani, C. dan T. Prasetyo. 2008. Penguatan kelembagaan pemasaran susu untuk mendukung pengembangan industri sapi perah di Jawa Tengah. Prosiding Seminar Nasional Prospek Industri Sapi Perah Menuju Perdagangan Bebas 2020. Jakarta. 21 April 2008. Pusat Penelitian dan Pengembangan Peternakan bekerjasama dengan Sekolah Tinggi Ilmu Ekonomi Keuangan dan Perbankan Indonesia.

Utami, H. D. and A. P. Seruni. 2013. Determinants of household labour allocation to small scale dairy farming activities (Case study at Pasuruan Regency, East Java, Indonesia). Livestock Res. Rural Dev. 25.

Wimaladharma, K. P. 1985. The impact of sociology on livestock production management. The proceedings in regional workshop on livestock production management. Manila: Asian Development Bank.

Yániz, J. L., P. Santolaria, A. Giribet and F. López-Gatius. 2006. Factors affecting walking activity at estrus during postpartum period and subsequent fertility in dairy cows. Theriogenology. 66: 1943-1950.

Yifat, D., B. Kelay, M. Bekana, F. Lobago, H. Gustafsson and H. Kindahl. 2009. Study on reproductive performance of crossbred dairy cattle under smallholder conditions in and around Zeway, Ethiopia. Livestock Res. Rural Dev. 21. 